Bangladesh J. Plant Taxon. 18(2): 153-157, 2011 (December)

(C) 2011 Bangladesh Association of Plant Taxonomists

\title{
THREE NEW RECORDS OF STERCULIACEAE FOR BANGLADESH
}

\author{
Md. Manzurul Kadir Mia ${ }^{1}$, Md. Oliur Rahman*, Md. Abul Hassan \\ AND A. Mozaharul Huq ${ }^{2}$ \\ Department of Botany, University of Dhaka, Dhaka 1000, Bangladesh
}

Keywords: Sterculiaceae; New records; Guazuma ulmifolia; Helicteres viscida; Sterculia urens; Bangladesh.

\begin{abstract}
Three species belonging to Sterculiaceae, namely Guazuma ulmifolia Lam., Helicteres viscida $\mathrm{Bl}$. and Sterculia urens Roxb. are recorded here for the first time for Bangladesh. Of these, the genus Guazuma is also a new generic record for the country. Updated nomenclature, important synonyms, description, ecology and geographical distribution are provided for each species.
\end{abstract}

\section{Introduction}

Sterculiaceae is moderately a large family consisting of some 70 genera and 1500 species, mainly of tropical and subtropical regions (Cronquist, 1981). Referring to the Sterculiaceae of Bangladesh Hooker (1874) reported 20 species under 10 genera from the present Bangladesh, whereas, Prain (1903) documented 9 species and 5 genera from the same area. Heinig (1925) recorded 14 species from Chittagong Collectorate and Hill tracts. Sinclair (1956) listed 6 species of this family from Cox's Bazar while Datta and Mitra (1953) registered 11 species from Dhaka and its suburb. Very recently Ahmed et al. (2009) added to our knowledge documenting 25 species of Sterculiaceae occurring in Bangladesh.

During the course of a revisionary work on Sterculiaceae of Bangladesh the first author visited the British Museum, London (BM), Royal Botanic Garden, Edinburgh (E) and Royal Botanic Gardens, Kew (K). At these herbaia he came across some herbarium specimens (Clarke 19931, Cowan 1618, Hooker \& T. Thomson 302) collected from the area now falls under Bangladesh, namely, Guazuma ulmifolia Lam., Helicteres viscida Bl. and Sterculia urens Roxb., respectively. None of these species appeared in the relevant publications of the regional flora, viz. Hooker (1874), Prain (1903), Heinig (1925), Raizada (1941), Datta and Mitra (1953), Sinclair (1956), Khan and Afza (1968), Khan and Banu (1972), Khan and Hassan (1984), Khan et al. (1994), Mia and Khan (1995), Rahman and Hassan (1995), Rahman and Uddin (1997), Uddin et al. (1998), Uddin and Rahman (1999), Khan and Huq (2001), Rahman et al. (2001), Rashid and Mia (2001), Uddin et al. (2003), Rahman (2004a, b), Hossain et al. (2005), Islam et al. (2009), Tutul et al. (2009, 2010), Rahman et al. (2010) and Uddin and Hassan (2010). Since there has been no record of occurrence of Guazuma ulmifolia Lam., Helicteres viscida Bl. and Sterculia urens Roxb. in any

*Corresponding author. Email: dr_oliur@yahoo.com

${ }^{1}$ Former Principal Scientific Officer, Bangladesh National Herbarium, Mirpur-1, Dhaka 1216, Bangladesh.

${ }^{2}$ Former Consultant-Taxonomist, University of Illinois at Chicago, USA. 
floristic works of Bangladesh, these species are reported here for the first time as new records for Bangladesh. Moreover, the genus Guazuma Mill. is also reported here as a new generic record for the country.

A detailed description with updated nomenclature, important synonyms, ecology and geographical distribution for each species are given below.

Guazuma ulmifolia Lam., Encycl. Math. Bot. 3: 52 (1789); Robyns in Ann. Miss. Bot. Gard. 51: 10 2, f. 7 (1964); Abedin et al. in Nasir \& Ali (eds), Fl. W. Pak. 99: 10 (1976); Malick in Sharma et al., Fl. Ind. 3: 424 (1993); Verdcourt in Dassanayake et al., Rev. Handb. Fl. Ceyl. 9: 421 (1995).

Guazuma tomentosa Kunth, in H.B.K., Nov. Gen. Sp. 5: 32 (1823). Mast. in Hook. f., Fl. Brit. Ind. 1: 375 (1874); Prain, Beng. P1. 1: 278 (1903).

Diuroglossum rufescens Turcz. in Bull. Soc. Nat. Mosc. 25 (2): 157 (1852).

Theobroma guazuma L., Sp. P1. : 782 (1753).

A moderate-sized tree, up to $25 \mathrm{~m}$ tall. Young twigs covered with rusty-brown or light grey stellate hairs. Leaves simple, tomentose, ovate or oblong-lanceolate, 7-13 x 3-6 cm, acuminate at the apex, obliquely cordate at the base, 3-5 nerved from the base, margin serrate, scabrid or glabrescent on upper surface, pubescent on lower surface; petiole 0.7-1.2 cm long, slender, covered with stellate hairs. Inflorescence axillary and terminal panicles, many-flowered. Flowers yellow; flower buds globose. Calyx campanulate, 5-lobed, lobes reflexed, connate below the middle, stellately hairy. Corolla 5-lobed, concave at the base, exceeding the calyx. Stamens 10, staminodes 5, lanceolate; anthers 2-lobed, lobes divergent, concealed in the hood of the petals. Ovary 5-locular, ovules many in each locule; style more or less connate. Fruit a capsule, woody, oblong, obtuse, tuberculate. Seeds albuminous.

Flowering and fruiting period: January to September.

Ecology: Secondary forests, growing in alluvial and clay soils.

Specimen examined: Naokhali: 30.10.1873, C.B. Clarke 19931 (BM).

Geographical distribution: Tropical America from Mexico to the northern part of Argentina and the middle part of Brazil. Also distributed in India, Sri Lanka and Indonesia.

Helicteres viscida Bl., Bijdr. 1: 79 (1825); Kurz, Fl. Burm. 1: 143 (1877); Gagnep. in Fl. Gen. I.-C. 1: 489 (1911); Ridl., Fl. Mal. Pen. 1: 281 (1922); Craib in Fl. Siam. Enum. 1: 175 (1925); Kou-mei, Fl. Reipubl. Popularis Sin. 49 (2): 161 (1984).

Helicteres pulchella Wall. ex Boj. in Hort. Maurit.: 35 (1837).

A shrub, 1-3 m tall, with stellate hairs on all parts. Leaves ovate, ovate-oblong to lanceolate, 6-15 x 4-10 cm, subcoriaceous, with soft hairs on lower surface, acute to cuspidate at the apex, cuneate or oblique at the base, margin irregularly dentate, secondary nerves 3-5 pairs; petiole 0.4-1.0 cm long, hairy. Inflorescence axillary, up to $3.5 \mathrm{~cm}$ long. Flowers white or yellow; 
pedicels articulate. Calyx funnel shaped, 1.4-1.8 cm long, velvety outside, 5-lobed, lobes unequal, acute. Corolla 2.5-3.2 cm long, spathulate, 5-lobed, lobes obtuse or retuse. Stamens 10; staminodes 5; filamens glabrous; anthers 2-celled. Ovary 5-locular, glabrous, each locule with many ovules, ovoid to oblong, surrounded by the ring of stamens; styles slender; stigma divided into 5, pin-like teeth. Fruit a capsule, oblong or cylindrical, 2.5-4.0 cm long, beaked, covered with shaggy hairs. Seeds many, globose to rhomboid.

Flowering and fruiting period: July to March.

Ecology: Evergreen forest, altitudes 30-340 m.

Geographical distribution: China, Vietnam, Laos, Thailand, Myanmar, Malay Peninsula and Indonesia.

Specimen examined: Chittagong: Jaldi Range, Boilchori, 2.12.1920. J.M. Cowan 1618 (E).

Sterculia urens Roxb., P1. Corom. 1: 25, t. 24 (1795); Fl. Ind. ed. Carey 3: 145 (1832); Wight \& Arn, Prodr. 1: 63 (1834); Mast. in Hook. f., Fl. Brit. Ind. 1: 355 (1874); Prain, Beng. P1. 1: 274 (1903); Malick in Shanma et al., Fl. Ind. 3: 470 (1993); Verdcourt in Dassanayake et al., Rev. Handb. Fl. Ceyl. 9: 432 (1995).

Cavallium urens Schott \& Endl., Melet. : 33 (1832).

A soft-wooded deciduous tree, up to $15 \mathrm{~m}$ tall, with white papery outer bark; twigs glabrescent, with distinct raised leaf scars and lenticels. Leaves crowded at the end of branchlets, palmately 3-5 lobed, coraceous, hairy on lower surface, $12-20 \times 10-20 \mathrm{~cm}$, acuminate to cuspidate at the apex, deeply cordate at the base, usually 5-nerved from the base; petiole very long, up to 20 $\mathrm{cm}$ long; stipules narrowly lanceolate, caducous. Inflorescence terminal, many flowered, $10-18 \mathrm{~cm}$ long, glandular pubescent. Flowers small, yellow; pedicels c 4mm long. Cayx 5-lobed, campanulate, 5-lobed, lobes oblong or narrowly triangular, 4-8 x 3-5 mm, hairy on both surface, calyx-tube as long as lobes. Male flowers: stamens 10; anthers sessile; staminodes 10 . Female flowers: ovary 5-6, ovoid, hairy; style hairy; stigma 5-6 lobed, recurved. Fruit a follicle, 2-6, oblong, ellipsoid or kidney-shaped, 4-6 cm long and 1-2 cm broad when young, densely rusty pubescent. Seeds 3-6, oblong to ellipsoid, black.

Flowering and fruiting period: October to February.

Ecology: Mixed deciduous forest.

Geographical distribution: Cambodia, India, Sri Lanka, Thailand and Vietnam.

Specimen examined: Chittagong : s. loc. 31.12.1850, J.D. Hooker \& T. Thomson 302 (K).

\section{Acknowledgement}

We would like to thank the authorities of the Royal Botanic Gardens, Kew, Royal Botanic Garden, Edinburgh and British Museum, London for herbarium and library facilities. 


\section{References}

Ahmed, Z.U., Hassan, M.A., Begum, Z.N.T., Khondker, M., Kabir, S.M.H., Ahmad, M., Ahmed, A.T.A., Rahman, A.K.A. and Haque, E.U. (eds.). 2009. Encyclopedia of Flora and Fauna of Bangladesh, Vol. 10. Angiosperm: Dicotyledons (Ranunculaceae-Zygophyllaceae). Asiatic Society of Bangladesh, Dhaka.

Cronquist, A. 1981. An Integrated System of Classification of Flowering Plants. Columbia University Press, New York.

Datta, R.B. and Mitra, J.N. 1953. Common plants in and around Dacca city. Bull. Bot. Soc. Beng. 7(1\&2): 1110.

Heinig, R.L. 1925. List of the plants of Chittagong Collectorate and Hill Tracts. Darjeeling.

Hooker, J.D. 1874. The Flora of British India. Vol. 1. L. Reeve \& Co. Ltd., England. pp. 353-379.

Hossain, M.M., Hassan, M.A. and Uddin, M.Z. 2005. A checklist of angiospermic flora of Lalmai Hills, Comilla, Bangladesh. Bangladesh J. Plant Taxon. 12(2): 85-96.

Islam, M.R., Uddin, M.Z. and Hassan, M.A. 2009. An assessment of the angiospermic flora of Ramgarh upazila of Khagrachari district, Bangladesh. Bangladesh J. Plant Taxon. 16(2): 115-140.

Khan, M.S. and Afza, S.K. 1968. A taxonomic report on the angiospermic flora of Teknaf and St. Martin's Island. Dhaka Univ. Studies, Part B. 16: 35-37.

Khan, M.S. and Banu, F. 1972. A taxonomic report on angiospermic flora of Chittagong Hill Tracts 2. J. Asiat. Soc. Bangladesh 17(2): 63-68.

Khan, M.S. and Hassan, M.A. 1984. A taxonomic report on the angiospermic flora of St. Martin's Island. Dhaka Univ. Studies, Part B. 32(1): 76-78.

Khan, M.S. and Huq, A.M. 2001. The vascular flora of Chunati Wildlife Sanctuary in south Chittagong, Bangladesh. Bangladesh J. Plant Taxon. 8(1): 47-64.

Khan, M.S., Rahman, M.M., Huq, A.M., Mia, M.M.K. and Hassan, M.A. 1994. Assessment of biodiversity of Teknaf Game Reserve in Bangladesh focusing on economically and ecologically important plant species. Bangladesh J. Plant Taxon. 1(1): 21-33.

Mia, M.K. and Khan, B. 1995. First list of angiospermic taxa of Bangladesh not included in Hooker's Flora of British India and Prain's Bengal Plants. Bangladesh J. Plant Taxon. 2(1\&2): 25-45.

Prain, D. 1903. Bengal Plants. Vol. 1. (Reprint edition 1981). Bishen Singh Mahendra Pal Singh, DehraDun, India. pp. 271-279.

Raizada, M.B. 1941. On the Flora of Chittagong. Indian Forester 67(5): 245-254.

Rahman, M.A. and Uddin, S.B. 1997. Angiospermic flora of Sitakund in Chittagong, Bangladesh. Bangladesh J. Plant Taxon. 4(1): 17-36.

Rahman, M.M., Rashid, M.H. and Rashid, S.H. 2001. Assessment of plant biodiversity of sand dune ecosystem along Cox's Bazar to Teknaf coast. Bangladesh J. Plant Taxon. 8(1): 27-45.

Rahman, M.O. 2004a. Second list of Angiospermic taxa not included in Hooker’s “Flora of British India” and Prain’s “Bengal Plants” - Series I. Bangladesh J. Plant Taxon. 11(1): 77-82.

Rahman, M.O. 2004b. Second list of Angiospermic taxa not included in Hooker's "Flora of British India” and Prain’s “Bengal Plants” - Series II. Bangladesh J. Plant Taxon. 11(2): 49-56.

Rahman, M.O. and Hassan, M.A. 1995. Angiospermic flora of Bhawal National Park, Gazipur (Bangladesh). Bangladesh J. Plant Taxon. 2(1\&2): 47-79.

Rahman, M.O., Uddin, M.Z., Tutul, E., Begum, M. and Hassan, M.A. 2010. Additions to the Angiospermic flora of Runctia sal forest, Bangladesh. Bangladesh J. Plant Taxon. 17(2): 167-181.

Rashid, S.H. and Mia, M.M.K. 2001. Angiospermic flora of Madhupur National Park, Tangail, Bangladesh. Bangladesh J. Plant Taxon. 8(2): 63-82.

Sinclair, J. 1956. Flora of Cox's Bazar, East Pakistan. Bull. Bot. Soc. Beng. 9(2): 92-94. 
Tutul, E., Uddin, M.Z., Rahman, M.O. and Hassan, M.A. 2009. Angiospermic flora of Runctia sal forest, Bangladesh. I. Liliopsida (Monocots). Bangladesh J. Plant Taxon. 16(1): 83-90.

Tutul, E., Uddin, M.Z., Rahman, M.O. and Hassan, M.A. 2010. Angiospermic flora of Runctia sal forest, Bangladesh. II. Magnoliopsida (Dicots). Bangladesh J. Plant Taxon. 17(1): 33-53.

Uddin, S.B. and Rahman, M.A. 1999. Angiospermic flora of Himchari National Park, Cox's Bazar. Bangladesh J. Plant Taxon. 6(1): 43-46.

Uddin, M.Z. and Hassan, M.A. 2010. Angiosperm diversity of Lawachara National Park (Bangladesh): a preliminary assessment. Bangladesh J. Plant Taxon. 17(1): 9-22.

Uddin, M.Z., Hassan, M.A. and Khan, M.S. 2003. An annotated checklist of angiospermic flora of RemaKalenga Wildlife Sanctuary (Habiganj) in Bangladesh II.a: Magnoliopsida (Dicots). Bangladesh J. Plant Taxon. 10(1): 79-94.

Uddin, S.N., Khan, M.S., Hassan, M.A. and Alam, M.K. 1998. An annotated checklist of angiospermic flora of Sita Pahar at Kaptai in Bangladesh. Bangladesh J. Plant Taxon. 5(1): 13-46.

(Manuscript received on 10 July 2011; revised on 3 December 2011) 